\title{
O SLOBODE AKO POLITICKEJ HODNOTE
}

TATIANA SEDOVÁ, Filozofický ústav Slovenskej akadémie vied, Bratislava, SR

SEDOVÁ, T.: On Freedom as a Political Value

FILOZOFIA, 76, 2021, No 2, pp. $81-96$

\begin{abstract}
The aim of the article is to investigate the issue of freedom as a political value, its relationship to the so-called reflexive freedom and its two historical forms: freedom as autonomy and freedom as authenticity. The introduction examines the problem of whether freedom belongs more to the domain of metaphysics or political philosophy, and discusses the ideas of existentialist understanding of freedom. The idea of negative liberty as the core of the liberal conception of justice is critically examined against the background of a summary of Honneth's ideas on reflexive, negative, and social freedom and its historical protagonists. The author emphasizes the weaknesses and the inability of the liberal concept of freedom and justice to solve mainly the problem of people with disabilities, global justice and issues related to species specificity.
\end{abstract}

Keywords: Freedom - Liberties - Negativ liberty - Liberal justice - Reflexive freedom - Social freedom - Arendt - Berlin - Camus - Williams - Honneth - Sartre - Individual autonomy - Authenticity

\section{Úvod}

Prečo je otázka slobody dôležitá? Existuje nejaká adekvátna definícia slobody, alebo pokusy o takúto definíciu stroskotávajú? Je sloboda nevyhnutná podmienka l'udskej existencie alebo vlastnost' konania? Ako súvisí sloboda a spravodlivost? Je vec slobody záležitost' metafyziky alebo politickej filozofie? Odpovede na tieto a mnohé d’alšie otázky spojené so slobodou, ktoré ponúkajú rozličné filozofické prúdy pričom názory jednotlivých myslitel'ov sa líšia a akcent na vzt’ah slobody ako hodnoty k iným hodnotám, ktoré utvárajú normatívne systémy spoločnosti, sa tiež interpretujú odlišne.

$\mathrm{V}$ texte mi ide hlavne o pojem slobody $\mathrm{v}$ zmysle politickej hodnoty, jej aspekty a súvislost' s ideou spravodlivosti, a nie o metafyzický problém slobody vôle. Hoci tento problém sa v metafyzike (napr. anomálny monizmus Davidsona ) stále tematizuje najmä v súvislosti s morálnymi vol'bami a postojmi, nazdávam sa, že empirické skúmanie determinant motivácie, utvárania postojov indivídua $\mathrm{v}$ mnohom zbavuje 
metafyzické úvahy o slobode vôle ich kúzla. ${ }^{1}$ Vzhl’adom na rozlíšenie metafyzického problému slobody a slobody ako politickej hodnoty sa súvislost' slobody a spravodlivosti tematizuje s akcentom na dve línie; jednak na akcentovanie slobody ako sebaurčenia a autonómie, jednak na slobodu $\mathrm{v}$ zmysle autentickosti. $\mathrm{V}$ tomto kontexte je potom zrejmé, prečo negatívna sloboda obmedzená na autonómiu ako predpoklad dobrého života v liberálnych koncepciách spoločnosti nestačí pri posudzovaní inštitúcií spoločnosti, ktoré majú na jednej strane garantovat' a umožňovat' slobodné sebaurčenie a jednak sú stelesnením hodnoty slobody. Potom je pochopitel'né, prečo problematika slobody organicky súvisí so spravodlivost’ou a dnes najmä s problematikou l'udských práv a ich legislatívnej ochrany. $Z$ tejto perspektívy je uvažovanie o slobode viazané vždy na konkrétny historický kontext. Sloboda je teda aj akýmsi svorníkom a spojením medzi autonómiou jedinca a spoločnost'ou a rôzne obmedzenia individuálnej slobody sú výrazom toho, do akej miery a aké prejavy autonómie sa podporujú a umožňujú zo strany spoločenských inštitúcii. Vlastne ony sú meradlom toho, čo je slobodné a neslobodné.

\section{K pojmu slobody v existencializme Sartra a Camusa}

Každý človek, každé indivíduum ako osoba, má skúsenost's fenoménom slobody, zažíva jednak jej výkon a realizáciu, jednak jej antinómie a protirečenia, napríklad v podobe napätia medzi tým, čo chcem, a tým čo reálne môžem; v podobe zlyhania, slabosti vôle, akrázie, alebo v podobe odsúvania rozhodnutia začat' konat', známeho ako prokrastinácia. O chápaní slobody by sa bezpochyby niečo relevantné dalo vydestilovat' aj z umeleckých diel, nech by sme mali na mysli akékol'vek druhy a žánre - od hudby až k románu. ${ }^{2} \mathrm{Ak}$ by som tematizáciu slobody v rozličných umeleckých druhoch a žánroch mala nejako sumarizovat' a previest' ju na spoločného menovatel'a, umenie zväčša zobrazuje a artikuluje internú stránku slobody, jej emocionálne prežívanie a rozličné prekážky vôle alebo pocit absencie slobody rozhodovania. Možno povedat', že umenie sa zameriava hlavne na indivíduum, jeho vôlu, sebavyjadrenie a autentickost' prejavu, a na to, čo sa uplatneniu jedincovej vôli, jeho autentickému prejavu, kladie do cesty ako prekážka. V tomto smere vynikol vo filozofii existencializmus, ktorý sa stal populárnym predovšetkým vd’aka svojej literárnej podobe, ktorú mu dali Sartre a A. Camus. Sartre dokázal aplikovat' fenomenológiu na l'udský život tak, že vo svojich poviedkach, románoch, hrách, ale aj vo filozofických traktátoch písal o telesnom vnímaní sveta, štruktúrach a náladách l'udskej existencie, ale najmä

\footnotetext{
${ }^{1}$ Napríklad pojem zlo ako výsostne metafyzický pojem sa Baron-Cohen usiluje nahradit' empiricky testovatel'ným pojmom empatia, pričom pri empatii odlišuje takzvanú kognitívnu a reaktívnu zložku. Pozri Baron-Cohen (2014, 15 - 53).

${ }^{2}$ Napríklad symfónia Jeana Sibeliusa, romány a hry existencialistov, ale aj iných (napríklad Hesse, Dostojevskij, Musil, Broch).
} 
o jednej téme, o tom, čo značí byt' slobodný. Hoci človeka determinuje tak biologická prirodzenost', ako aj rozličné aspekty sociálneho a kultúrneho prostredia, nič z toho nepredurčuje, akí napokon v konečnom dôsledku budeme. Sami seba ustavične formujeme, utvárame a modelujeme. Sartre pokladal tému slobody za absolútne klúčcovú, pričom odmietal všetky esencialistické koncepcie, či už biologické, sociologické alebo psychologické, lebo človek nie je len svojou faktickou existenciou, ktorá je podmienená sociálne a biopsychologicky, ale vždy je aj bytím pre seba; v každej situácii má toto bytie pre seba možnost' vol'by, možnost' angažovat' sa v situácii. Sartre sa zameriava ma ontologické konštituovanie slobody, nie na normatívny problém, ako zabezpečit' a v akej miere slobodu indivídua v spoločnosti; ale tam, kde sa Sartre venuje horizontu spoločného sveta l’udí, ukazuje sa, že jeho pojem slobody je podla A. Honnetha svojskou radikalizáciou Hobbesovho chápania. Toto spojenie, na prvý pohl'ad dost' nezvyčajné, získa na presvedčivosti, ak sa zameriame - podl'a Honnetha - na neprítomnost' reflexie pri uvažovaní o cieloch konania. Totiž ani pre Sartra slabost' vôle ani psychická zát'až nie sú limitom slobody, lebo aj v takýchto prípadoch sú výrazom vol'by, ktorou sa určuje, akú podobu existencie si človek volí. Ked' sa subjekt rozhoduje pre nejakú podobu spôsobu života, nič ho neobmedzuje, ani ohl'ady na iného, ani jeho osobný príbeh či identita. V momente existenciálnej vol'by nemáme k dispozícii kritériá, ktorými by sme mohli ospravedlnit' svoju vol'bu sami pred sebou a pred inými. Akt chcenia je tu absolútne nedeterminovaný. Spontánnostou bez spätnej reflexie sa projektuje do nejakej možnosti existencie. Sloboda spočíva v samotnom akte rozhodnutia ako postačujúcej podmienky slobody ${ }^{3}$ (Honneth, $45-46$ ). Hobbesova predstava slobody vychádza $\mathrm{z}$ toho, že indivíduum sleduje svoje vlastné záujmy, pričom mu v tom nebránia nijaké vonkajšie sily, súvisí s centrálnym nárokom moderného individualizmu, s jeho apelom na právo subjektu na akékol'vek osobitosti; čo bolo nezamýšlaným dôsledkom Hobbesovej snahy ponechat' na indivíduu výber vlastných ciel'ov. Ako to formuluje Honneth: “... podporil tak celkom proti svojmu vlastnému presvedčeniu vznik myšlienky slobody, pre ktorú je vrcholom obrana idiosynkrázie“ (Honneth 2018, 44). Honneth teda legitímne pokladá aj Sartrovo chápanie individuálnej slobody, ktoré eliminuje reflexivitu uvažovania o ciel’och za svedectvo príbuznosti medzi Hobbesovým motívom a Sartrovým existenciálnym prinútením. Skúmat', reflektovat' povahu ciel'ov, zámerov subjektu, nepatrí k podmienkam slobody, nech už tieto ciele generuje spontánne vedomie, alebo sklony prirodzenosti. Téza, že existencia predchádza esenciu mala vyjadrovat' to, že sme svojou vlastnou

\footnotetext{
${ }^{3}$ Honneth analyzuje spojenie medzi Hobbesom a Sartrom na základe absencie reflexivity a potreby uvažovat' o ciel'och a ich motivácie, aby ukázal, že idea negatívnej slobody sa stala pevnou súčast'ou moderných predstáv najmä preto, lebo ponúkla zdôvodnenie snahám o svojbytnost'. Pozri Honneth (2018, 43 - 46).
} 
slobodou. ${ }^{4}$ Práve v tomto zmysle človek akoby bol odsúdený na slobodu, a teda aj na zodpovednost'. Prirodzene, toto chápanie, ktoré je skôr ontologicko-filozofické ako sociálno-politické, možno kritizovat' z rôznych aspektov, ale svojím naliehavým apelom na neoddelitelnost' slobody od konkrétnej situácie a akcentom na právo na vyjadrenie individuálnych zvláštností nastol'uje problém, ako určit' nevyhnutné a postačujúce podmienky individuálnej slobody vzhl'adom na zdroje zámerov, ciele, ktoré sú mimo sféry spontánneho vedomia a individuálnej autonómie.

Camusova tematizácia slobody a oslobodenia sa rozvíja vo vzt’ahu $\mathrm{k}$ absurdite existencie, najmä v kontexte smrti, a sloboda je tu pochopitel'ná len v rámci mojej individuálnej skúsenosti. Podl’a Camusa slobodu nemôžem poznat', môžem mat' o nej len predstavu na základe vlastnej skúsenosti, prežívania. „Preto nechcem zdržiavat' prílišným vyzdvihovaním či vymedzovaním pojmu, ktorý mi uniká a stráca zmysel, len čo presiahne rámec mojej individuálnej skúsenosti. Neviem pochopit', čím by mohla byt' sloboda, ktorá by mi bola daná nejakou vyššou bytost'ou. Stratil som zmysel pre hierarchiu hodnôt. Slobodu môžem chápat' len tak, ako ju chápe väzeň alebo moderné indivíduum uprostred štátu. Jediná sloboda, ktorú poznám, je sloboda ducha a konania. Ak mi teda absurdno berie všetky moje nádeje na večnú slobodu, na odplatu mi vracia a zväčšuje moju slobodu konania. Táto strata nádeje budúcnosti znamená zvýšenú disponibilitu človeka“ (Camus 1993, 43). Sloboda je bremenom, samotou, stratou komunikácie, absurdno nás síce spoluurčuje, ale vzbura, konkrétny čin , naša vol'ba, náš život naplnený svojím konaním, to je afirmácia slobody a požiadavky zodpovednosti. Toto poznanie absurdna vytvára novy modus ludskej existencie, prostredníctvom neho si utvárame vzt’ah $\mathrm{k}$ sebe aj k iným. Slobodný človek je osamelý, pochybuje o zmysle vecí, ale napriek tomu revoltuje a búri sa, či už snahou byt' niekým alebo niečím napriek poznaniu márnosti aj napriek poznaniu ako takému. ${ }^{5}$ Hoci existencializmus aj v súvislosti s tematizáciou slobody má už svoju hviezdnu hodinu za sebou, jeho odkaz v súčasnosti oživa a možno ho domýšl'at' a premýšl'at' dvoma smermi; jeden predstavuje otázka slobody a jej podôb na osobnej a sociálnokolektívnej úrovni; druhý zahŕňa politické aspekty slobody, jej inštitucionálne podmienky. Kým v prvom prípade vstupuje do hry problém autentickosti a autonómie indivídua, v druhom prípade je rozhodujúci vzt’ah slobody, respektíve slobôd k l’udským právam, ich zdroju, platnosti a rozširovaniu. ${ }^{6}$

\footnotetext{
${ }^{4}$ Slovenská autorka D. Smreková patrí k znalcom Sartrovho myslenia a vo svojich prácach dôkladne zmapovala a interpretovala historické, antropologické aj sociálne aspekty Sartrovho existencializmu vrátane problematiky slobody. Pozri Smreková (2013, 611 - 631).

${ }^{5}$ D. Hajko v doslove s názvom Štastný Sizyfos (Pokus o Alberta Camusa) zasvätene analyzuje a interpretuje motívy a hlavné tézy Camusovho existencializmu, jeho skúmanie hraníc slobody a jej vzt'ahu s mocou, neeliminovatel'nost' absurdna a revolty. Pozri Camus (1993, 238 - 246).

${ }^{6}$ Pozri Sedová $(2020,324-330)$.
} 


\section{Je sloboda hlavne metafyzický problém?}

Ak ostaneme len v rámci filozofie, fenomén slobody, jej ,proteovský“ (Berlin) pojem možno analyzovat' predovšetkým v rovine filozofickej antropológie a morálnej psychológie, v rovine ontologickej - ako postupovali existencialisti -, ale aj v rovine sociálnej a politickej filozofie a filozofie práva, aby som spomenula hlavné oblasti, ktoré z rozličných zorných uhlov tematizujú rozličné aspekty slobody. Hoci ostáva zväčša netematizovaným, ale relevantným predpokladom aj to, kto vlastne je nositel'om a aktérom slobody, autonómie a autentickosti. Na prvý pohl'ad to vyzerá tak, akoby problematika slobody bola jednou z nosných tém tradičnej metafyziky na jednej úrovni s otázkami bytia, jeho foriem a vlastností, s otázkou poznania a pravdy, ale Arendtová demonštrovala, že možno obhajovat' aj opačné stanovisko (Arendtová 2002, 129 152). ${ }^{7}$ Arendtová akcentuje a podčiarkuje ten aspekt, že v prípade slobody ako problému u antických myslitel’ov máme do činenia so slobodou v zmysle úniku pred svetom, oslobodením od bremena života a verejnej sféry. Antika sa orientovala na slobodu myslenia, po ktorej nasledovalo krest'anstvo s akcentom na ideu slobodnej vôle, na čo nadviazal aj novovek; rozhodujúce je to, že žiadny z týchto prístupov (antický ani krest’anský) sa nezakladá na reflektovaní politického konania. „Naša filozofická tradícia sa zhoduje na tom, že sloboda sa začína tam, kde l'udia opustia sféru politiky, v ktorej dominuje množstvo; zhodne sa na tom, že slobodu možno okúsit' len v interakcii so sebou samým, nech už v podobe dialógu, ktorý sa od čias Sokrata nazýva myslením, alebo v podobe vnútorného konfliktu so sebou samým, vnútorným zápasom medzi tým, čo by som robit' mal, a tým, čo naozaj robím, v podobe boja, ktorého vražednú dialektiku odhalila nejednoznačnost' a bezmocnost' l'udského srdca najskôr Pavlovi a potom Augustínovi“ (Arendtová 2002, 140). Arendtová tiež poznamenáva, že pre politiku sa stalo priamo fatálnym filozofické stotožnenie slobody ako slobody vôle s ideou suverenity. Podl'a nej suverenita a sloboda vedl'a seba nemôžu jestvovat', lebo človek je všetko iné, len nie suverén, a sloboda jedného alebo kolektívu je možná len potlačením slobody, ergo suverenity iných (Arendtová 2002, 146 - 147). Pre Arendtovú je preto sloboda nerozlučne spojená so spoločnost'ou, umožňuje ju len interakcia s inými a interná podoba slobody ako dialógu so sebou je teda až sekundárna, odvodená téma. V súvislosti s takouto interpretáciou ideou slobody však treba mat' na pamäti, že rozšírená vžitá predstava o Aténach ako kolíske demokracie, slobody a politických cností nie je historicky adekvátna, ako upozorňuje napríklad F. Zakaria, lebo sloboda $v$ dnešnom chápaní je najmä sloboda jedinca, jeho myslenia a konania proti svojvôli moci, ktorú z historickej perspektívy reprezentoval predovšetkým štát. ${ }^{8} \mathrm{Za}-$ karia pripomína konštatovanie B. Constanta, ktoré oceňujúco uvádza aj B. Williams,

\footnotetext{
${ }^{7}$ Arendtová $(2002,129-152)$.

${ }^{8}$ Pozri kapitola 1, čast' Svoboda, stará a nová (Zakaria 2013, 332 - 334).
} 
že hoci si starovek cenil slobodu spojenú s republikánskymi cnost’ami, tieto hodnoty vyrastali a boli späté s podmienkami starovekého sveta a pokus aplikovat' a presadzovat' tieto predstavy na moderný svet môžu spôsobit' katastrofu, čo sa vo Francúzskej revolúcii počas jakobínskeho teroru aj reálne stalo. ${ }^{9}$

\section{Negatívna sloboda ako kl'účový problém modernity a politického liberalizmu}

Akcent na slobodu v liberalizme, ktorý sa zrodil zo zápasov proti autokracii, proti svojvôli politickej moci a autorite, ktorým sa vyznačuje klasický aj súčasný liberalizmus spolu s oddelením privátnej a verejnej sféry a obhajoba individuálnej slobody interpretovanej predovšetkým ako negatívna sloboda; to sú predstavy, ktoré doposial' určujú pôdorys liberálneho uvažovania o slobode, spravodlivosti a rovnosti. Tento akcent na slobodu ako neprítomnost' obmedzení individuálnej vôle, teda negatívnej slobody, má svoj pôvod u Th. Hobbesa, podl’a ktorého človek je slobodný do tej miery, do akej mu nijaké vonkajšie prekážky nebránia v realizovaní jeho ciel'ov. Absolútna sloboda by znamenala, že človek dosiahne všetko, čo chce. A k takému stavu mali blízko Adam a Eva v raji, kde mali zakázané jest' len jedno ovocie z jedného stromu. Tento koncept slobody u Hobbesa súvisí s pojmami prirodzeného práva a prirodzeného zákona. Hobbes práva definuje vzhl'adom na slobody v otázkach použitia všetkej moci a prostriedkov na zachovanie vlastného života; a prirodzený zákon definuje vzhl'adom na reštrikcie. Právo nám potom naznačuje a ukazuje, čo možno robit', kým prirodzený zákon nás obmedzuje v tom, čo nesmieme robit'. „Teda [...] o tom, čo je sloboda, nemožno ponúknut' nijakú inú evidenciu, než skúsenost' každého človeka, $\mathrm{v}$ reflexii a pripomenutí toho, čo sa deje v jeho mysli, t. j. čo mieni, ak o nejakom konaní povie..., že je slobodné. Táto reflexia o sebe samom ho môže uspokojit' [...], ak je slobodným aktérom, ktorý môže vykonat', čo chce a kedy chce; teda že sloboda je neprítomnost' vonkajších prekážok. Ale pre tých, ktorí zo zvyku nehovoria o tom, čomu rozumejú, ale čo si predstavujú, ked' začujú také slová, nedokáže uspokojit' nijaký argument, lebo skúsenost' a fakt sa nedajú overit' prostredníctvom argumentácie druhých, ale len na základe vlastného rozumu a pamäte“ (preklad T. S. Hobbes: On Liberty and Necessity, English Work 4, 275). ${ }^{10}$

\footnotetext{
${ }^{9}$ Pozri Williams $(2011,148)$.

10 "For [...] what liberty is; there can no other proof be offered but every man's own experience, by reflection on himself, and remembering what he useth.in his mind, that is, what he himself meaneth when he saith an action [...] is free. Now he that reflecteth so on himself, cannot but be satisfied [...] that a free agent is that can do if he will, and forbear if he will; and that liberty is the absence of external impediments. But to those that out of custom speak not what they conceive, but what they conceive when they heard... such words, no argument can be sufficed, because experience and matter of fact are not verified by other mens' arguments, but by every mans' own sense and memory."
} 
Pojem negatívnej slobody a jej ústredný motív - neprítomnost' obmedzení, nátlaku a prekážok - sa tradoval a modifikoval od Locka, Constanta, Rousseua až k Berlinovi, ktorého esej Dva pojmy slobody sa stala doslova paradigmatickou ukážkou liberálneho prístupu $\mathrm{k}$ negatívnej a pozitívnej slobode a nájdeme ho aj u súčasných predstavitel’ov Buchana a Nozicka. ${ }^{11}$ Berlin konštatuje, že v dejinách ideí sa objavujú dve chápania slobody, ktoré formulujú odpovede na dve rôzne otázky. Prvá otázka sa týka rozsahu sféry konania; čo môžem slobodne, nezávisle robit' alebo kým môžem slobodne byt'. Je to oblast', do ktorej druhý nesmie zasahovat', zatial' čo druhá otázka sa viaže k pôvodcovi, zdroju kontroly alebo prinútenia. „Aká je oblast', v rámci ktorej je, alebo by malo byt', subjektu - človeku alebo skupine l'udí - dovolené robit' to, čo je schopný robit', alebo byt' tým, čím je schopný byt', a to bez zasahovania iných l'udí?“ (Berlin 1993, 23) Odpoved’ou je negatívna sloboda, sféra, ktorá nepripúšt’a nátlak, prinútenie, hoci je otázne, čo treba chápat' pod prinútením a prekážkami, lebo každá neschopnost' dosiahnut' ciel' nie je výrazom neslobody... A frustrácia, ktorá sprevádza moju neschopnost' presadit' svoju vôl'u vo svete, tiež nie je prejavom politickej neslobody.

Druhý pozitívny pojem slobody je výsledok odpovede na otázku „ kým som riadený?“ alebo „kto to hovorí , čo som a čo nie som, čím by som mal byt' alebo čo by som mal robit?"“ (Berlin 1993, 30) Podl'a Berlina sa tieto dve podoby slobody vyvíjali historicky protichodne a zrážka medzi nimi viedla $\mathrm{k}$ dvom protikladným ideológiám (autoritatívne, totalitne a liberálne), ktoré vychádzajú aj z odlišnej perspektívy pri interpretácii človeka a jeho prirodzenosti.

Berlin kritizuje ideu pozitívnej slobody a analyzuje jej historické podoby, pričom dôvodí, že metafora toho, že som sám sebe pánom sa vykladala na pozadí rozštiepenia jedinca na jeho empirické, heterogénne $j a$ a vyššie transcendentné $j a$, ktoré sa vyznačuje racionalitou a autonómiou, pričom práve transcendentné $j a$ má plnit úlohu krotitel'a empirického ja. Prianie regulovat' a riadit' sám seba tak nadobudla dve podoby: „... po prvé formu sebanegácie, aby človek získal nezávislost'; a po druhé formu sebauvedomenia alebo totálnej sebaidentifikácie so zvláštnym princípom alebo ideou,

\footnotetext{
${ }^{11}$ Prirodzená sloboda človeka spočíva v tom, že je nezávislý od akejkol’vek vysej moci na zemi, že nie je podrobený vôli alebo zákonodarnej autorite človeka, ale jeho pravidlom je len prirodzený zákon. Sloboda človeka v spoločnosti spočíva v tom, že nie je podriadený nijakej inej zákonodarnej moci než tej, ktorá bola stanovená zmluvou v štáte, ani nie je podrobený panstvu nejakej vôli alebo obmedzeniu nejakého zákona okrem toho, ktoré stanoví legislatíva na základe v nej stelesnenej dôvery“ (Locke 1965, 42). „Sloboda sa l'ud'om ukazovala v rôznych časoch a v rôznych podobách; nespája sa výlučne s istým konkrétnym sociálnym zariadením a stretávame sa s ňou aj inde ako $\mathrm{v}$ demokraciách [...] Výhody slobody sa prejavia len z dlhodobého hl'adiska, a nie je vždy l'ahké poznat' príčinu, z ktorej sa zrodili. Výhody rovnosti sú okamžite zrejmé a l'udia každodenne pozorujú, ako tečú zo svojho zdroja“" (Tocqeuville 1992, 74).
} 
aby sa dosiahol istý ciel'."V tom vidí zvody a hrozby autoritárstva pre individuálnu slobodu, hoci tvrdí aj na adresu negatívnej slobody, že : „Stačí dostatočná manipulácia s definíciou človeka a sloboda môže znamenat' všetko, čo si želá manipulátor“ (Berlin1993, 34). Berlin obhajuje liberalizmus s jeho akcentom na negatívnu slobodu ako sféru individuálnej nezávislosti pred zasahovaním iných a obhajuje pluralitu životných ciel'ov, „životné experimenty“ s právom na pochybenie omylu, s uvedomením, že na niektoré odpovede nedosiahneme ani v praxi, ani v ideálnom svete celkom rozumných a dobrých l'udí. Mieru slobody, potrebu jej obmedzovania treba posudzovat' aj cez prizmu iných hodnôt - nech už bezpečnosti, rovnosti, spravodlivosti, št'astia -, lebo aj tieto sú výrazom základných túžob indivídua, práve tak ako túžba po slobode.

„Pluralizmus s mierou „negatívnej slobody“ $z$ neho vyplývajúcej sa mi vidí pravdivejším a humanistickejším ideálom ako ciele tých, ktorí hladajú vo vel'kých, disciplinovaných, autoritárskych štruktúrach ideál „pozitívneho sebariadenia“ tried, národov alebo celého l'udstva, je pravdivejší, pretože aspoň uznáva fakt, že l'udských ciel’ov je vel'a, že všetky z nich nie sú súmeratel'né a že sú stále vo vzájomnej rivalite. Podl'a mňa prijat' predpoklad, že všetky hodnoty možno merat' jedným meradlom, akoby šlo o záležitost' preskúmania určenia najvyššej z nich, znamená nebrat' do úvahy naše poznanie, že l'udia sú slobodné subjekty, a predstavovat' morálne rozhodnutie ako operáciu, ktorú možno v podstate uskutočnit' logaritmickým pravítkom“ (Berlin 1993, 68-69).

Bernard Williams a Axel Honneth a tematizovanie slobody ako politickej hodnoty Hoci Berlinovo rozdelenie na pozitívnu a negatívnu slobodu a vysvetlenie tohto rozdielu ako slobody pre a slobody od sa široko akceptovalo, Williams, reprezentant liberálneho chápania slobody $\mathrm{v}$ intencii politickej hodnoty a kontraktualistickej idey, odmieta toto rozdelenie a problematiku slobody situuje do politického kontextu, pričom ju tiež nepokladá za metafyzický problém slobody vôle, ale za istú schopnost' konat' alebo nekonat' z vlastného rozhodnutia. ${ }^{12}$ Williams vychádza z takzvanej primitívnej slobody, teda že nám nijaký nátlak druhého nebráni v niečom, čo chceme vykonat', od ktorej prechádza k politickej slobode. Samozrejme, povaha a rozsah prekážok, ktoré vystupujú ako nátlak, sa interpretujú rôzne (násilie, hrozby trestu, spoločenský tlak verejnej mienky, súperenie, ked’ sa jeden súper snaží zabránit’ druhému $\mathrm{v}$ dosiahnutí cielaa, nezamýšl'ané dôsledky iného konania, ktoré neboli zamerané na pôvodcu, vedlajšie dôsledky usporiadania, ktoré štrukturálne znevýhodňujú konajúcich) (Williams 2011, 133 - 134).

${ }^{12}$ Pozri Williams (2011, 133). 
Primitívna sloboda je podl'a neho protopolitický pojem, ktorý je elementárnym javom l'udskej existencie a ktorý však už signalizuje politiku. Williams rozvíja hobbesovský motív, ako sa z neporiadku formuje poriadok a generuje sa politická sloboda predpokladajúca autoritu, ktorá môže legitímne vyvíjat' nátlak. Štát stelesňuje takúto autoritu a v tomto zmysle st'ažnosti, že štát je sám osebe útokom na slobodu, ako to vidia anarchisti, nepokladá za oprávnené (Williams 2011, 141). „,.. existencia štátu sama osebe nie je útokom na slobodu ani jej obmedzením (hoci určité formy štátu môžu k tomu prirodzene smerovat'. Okrem toho nejde iba o slovičkárenie pri pochopení slova „sloboda“; nemusíme sa zhodovat' ani na tom, že ak je jednotlivec občanom štátu, je toto samo osebe obmedzením jeho primitívnej slobody. Dôvodom je to, že rozsah slobôd, ktoré by požíval bez štátu, je neurčitý, alebo v každom prípade vel'mi obmedzený“ (Williams 2011, 141).

Primitívna sloboda sama osobe nezakladá nárok v zmysle práv spojených so slobodou, ale tento nárok je užitočný pre rozlišovanie medzi politickou slobodou a primitívnou slobodou. „Myšlienka legitímneho nároku na slobodu však implikuje právnu koncepciu a platnú autoritu, ktoré môže podobný nárok legitímne uznat' alebo zamietnut', a politickí oponenti nemusia vždy svoju situáciu pochopit' rovnako“ (Williams 2011, 142).

Nechut', odpor, frustráciu, ktorú pocit’ujem voči obmedzujúcim opatreniam, nie sú nevyhnutne tým, čím platíme za obmedzenie slobody, lebo v modernej spoločnosti predpoklad rozsiahlej a rovnocennej slobody je spojený s jej klúčcoými činnost'ami. Moderná idea slobody kráča ruka v ruke s univerzálnou pravdou, že každá legitimizácia predpokladá a vyžaduje niečo viac, než len holé donútenie. Podl’a Williamsa ide o to, že legitimizačný príbeh modernity sa väčšmi približuje pravde v tom zmysle, že rozkladá predmoderné predstavy o predchádzajúcich legitimačných príbehoch a umožňuje porozumenie hierarchie nerovností a obmedzenie aktivít jedných občanov druhými. V tomto duchu potom Williams tvrdí, že moderné spoločnosti zabezpečujú a garantujú viac slobody ako minulé spoločnosti. „Samozrejme sloboda, ktorú chcú, je pochopená alebo koncipovaná tak, ako to zodpovedá modernej dobe, ale to neznamená, že ich prísl’ub sa točí v kruhu, alebo je platný. Patronuje ho idea, že bez ohl'adu na to, čo moderné spoločnosti odstránili alebo znemožnili, môžu ponúknut', a možno zachovat' koncepciu slobody s menšími obmedzeniami, a predovšetkým pravdivejšie motivovanými, než tomu bolo v minulosti vo väčšine spoločností" (Williams 2011, 155).

Hoci, ako tvrdí Honneth, medzi ideami moderny, ktoré medzi sebou súperili (idea rovnosti, prirodzeného práva, romantická obhajoba ja s jeho zvláštnost’ami, idea spravodlivosti), najväčší vzostup zaznamenala práve idea negatívnej slobody, teda chápanie, že sloboda je maximálne realizácia vlastných zámerov bez externých zábran 
a prekážok, sloboda $\mathrm{v}$ zmysle autonómie indivídua je teda aj mostom medzi individuálnym ja a spoločenským poriadkom. ,Zatial čo všetky ostatné hodnoty modernity sa vzt’ahujú bud' na orientačný horizont jednotlivca, alebo na normatívny rámec spoločnosti ako celku, iba myšlienka slobody jednotlivca spája tieto dva relačné veličiny: predstavy o tom, čo je dobré pre jednotlivca, zároveň obsahujú pokyny na vytvorenie legitímneho spoločenského poriadku (Honneth, 2018, 34).“

Skutočnost', že pravidlá spoločenského spolužitia a ich normatívna platnost' sa posudzujú na pozadí myšlienky, či vyjadruje sumu sebaurčenia jedincov, alebo zabezpečuje podmienky na sebaurčenie. Tento moment vyústil do zbliženia idey slobody a spravodlivosti. Centrálne postavenie individuálnej slobody sa transportovalo aj do ostatných etických vzt’ahov. „Nezdá sa, že by dnes existovala nejaká sociálna etika alebo kritika spoločnosti, ktorá by presahovala ideový horizont, ktorý sa zjavil spojením predstavy spravodlivosti s myšlienkou autonómie počas vyše dvoch storočí modernity“ (Honneth 2018, 35).

\section{Sloboda medzi autonómiou a autentickost'ou}

Prít'ažlivost' tejto idey zrejme spočíva $v$ predstave, že je nevyhnutné zabezpečit' jedincovi bezpečnú, chránenú sféru konania bez nejakého nátlaku a zodpovednosti. Všetky teórie vychádzajú z fikcie prirodzeného stavu, ktorého konkrétne deskripcie sa u jednotlivých myslitel'ov odlišujú, ale predstava o neobmedzenej realizácii zámerov indivídua ostáva rovnaká. Napokon každá snaha zmiernit' Hobbesov brutálny stav všeobecnej vojny každého s každým tak, že sa doň zaviedli nejaké prirodzené morálne zákony, v konečnom dôsledku vyústili do určenia nejakých obmedzení modelu negatívnej slobody. Problém spravodlivosti v zmluvných koncepciách sa začína tým, že indivíduá majú pôvodne jedinú vol'bu, presadzovat’ individuálny kalkul užitočnosti, a legitimita politického štátneho usporiadania sa posudzuje jedine podla naplnenia individuálnych záujmov. Liberálna teória spravodlivosti je vlastne spravodlivost' bezpečnosti, ktorá spočíva $\mathrm{v}$ legitimizácii obmedzení nevyhnutných pre mierovú koexistenciu jednotlivých subjektov. Negatívna sloboda sa dostáva do kolízie s individuálnym sebaurčením, lebo nedokáže uchopit' a tematizovat' to, že ciele konania sú plodom slobody. Liberalizmus ponecháva ciele v kompetencii kauzálne pôsobiacich síl. Formovanie ciel'ov determinuje kauzalita, ktorá sa bud' spája s egoistickou prirodzenost'ou subjektu, jeho predreflexívnou spontánnost'ou, náhodnost'ou individuálnych prianí, alebo túto kauzalitu určuje nejaká anonymná duchovna sila. No individuálne sebaurčenie predpokladá prekročenie tejto motivačnej roviny kauzálnych síl a zameranost' subjektu do jeho vnútra, čo sa nazýva reflexívnou slobodou. Túto intenciu, zameranost' na svoje myslenie, ktorú Berlin označuje za pozitívnu slobodu, iní - napríklad Honneth - označujú za reflexívnu slobodu (Honneth 2011, 54 - 74). Honneth 
rozoberá to, že idea reflexívnej slobody, na rozdiel od negatívnej slobody, má svoju predhistóriu, lebo už od antiky sa vedelo, že ak má byt' jedinec slobodný, musí ovládat' svoju vôl'u a kontrolovat' svoje rozhodnutia. Predstava o reflexívne slobode sa potom začína na úrovni vzt'ahu subjektu $\mathrm{k}$ sebe samému. „... podl'a nej (idey reflexívnej slobody) slobodným je také indivíduum, ktoré sa dokáže vzt'ahovat' $\mathrm{k}$ sebe samému tak, že svoje konanie podriad’uje len svojím vlastným zámerom“ (Honneth 2018, 55). Toto podriadenie a vlastné zámery sa však dá rozlične interpretovat', pričom kl’účovým je rozlišovanie medzi autonómnym a heteronómnym konaním. $\mathrm{V}$ tomto bode je rozhodujúce stanovisko Rouseaua, že slobodným nie je subjekt vtedy, ked' jeho zámeru nebránia prekážky vonkajšieho sveta, ale vtedy, ked' sa zámer niečo realizovat' opiera o jeho vôlu. Akonáhle indivíduum koná podla svojej vôle, a nie pod tlakom svojej prirodzeno-prírodnej prirodzenosti , koná slobodne, kým v prípade heteronómneho konania je len vnímajúcou bytost'ou. Samozrejme, vel'kým problémom ostalo, ako vysvetlit' fenomén vôle a jej vlastnosti. To bola cesta, po ktorej sa vydal aj Kant, a to s dôrazom na autonómiu a sebaurčenie vôle, ktorá sama sebe určuje zásady konania.

Iná cesta vedie od Rousseaua ${ }^{13} \mathrm{k}$ autentickosti a reflexivita individuálnej slobody je založená na tom, že človek si v procese reflexie osvojí a artikuluje svoju vlastnú autentickú vôl'u. ${ }^{14}$ Napätie a protiklady medzi sebaurčením a sebauskutočnením, medzi autonómiou a autentickost'ou, vyznačili cestu, ktorou sa potom uberalo myslenie o reflexívnej slobode. Obe idey sa v moderne definitívne očistia od svojich transcendentálnych, metafyzických predpokladov. V prípade Kanta to znamenalo jednak empirické prehodnotenie autonómie alebo intersubjektívne revidovanie reflexívnych výkonov. ${ }^{15}$

Podobne sa transformovali aj Herderova idea sebauskutočnenia, ktorá pôvodne súznela $\mathrm{v}$ jednote $\mathrm{s}$ autentickost'ou, ktorá sa postupne zbavila predstavy o fixnom $j a$. Lenže dnes sa tam, kde u Herdera vládla jednota (autentickost' a sebauskutočnenie), roztvorila priepast'. Reflexívna sloboda $\mathrm{v}$ zmysle sebauskutočnenia sa realizuje iným konaním, než aké sa predpokladá v prípade utvárania autentickej vôle. Honneth oprávnene upozorňuje na to, že pokial' ide o spravodlivost', na rozdiel od idey negatívnej slobody, ktorá smeruje k systému egoizmu, reflexívna sloboda smeruje k so-

${ }^{13}$ Emil, Vyznania savojského vikára, Nová Héloise.

${ }^{14}$ Podl'a Honnetha napr. Johann Gottfried Herder (Vom Erkennen und Empfindender menschlichen Seele) rozvíja predstavu, že slobodná vôla je výrazom vlastných autentických želaní, a jeho predstava kladie dobro jednotlivca nad každé normatívne všeobecné dobro. Pozri Honneth $(2018,62)$.

${ }^{15}$ Ako uvádza Honneth, to, čo podla Kanta bola nejaká schopnost' noumenálneho subjektu, sa interpretuje ako nejaký komplex empirických schopností (toto chápanie sa objavuje v celom spektre koncepcií morálnej autonómie (napríklad Freud, Paiget) a druhá línia rozvíja intersubjektívnu teoretickú reformuláciu (Apel, Habermas), teda to, čo bolo výkonom izolovaného subjektu, sa interpretuje ako výkon komunikácie jazykového spoločenstva. Pozri Honneth $(2018,64)$. 
ciálnemu systému kooperácie, ale základne inštitúcie spravodlivého usporiadania spoločnosti budú závisiet' od toho, či sa reflexívna sloboda chápe v intencii zákonodarstva alebo sebauskutočnenia. Potom dospejeme aj k odlišným charakteristikám fundamentálnych inštitúcii, ktoré umožnia, aby indivíduá realizovali svoju slobodu. Idea reflexívnej slobody tak musí referovat' aj na to, aké sociálne podmienky umožňujú praktizovat' slobodu, ktorá vyžaduje jej inštitucionálne rozšírenie.

\section{Sloboda indivídua a inštitúcie}

Ani negatívna, ale ani reflexívna sloboda si nevšímajú sociálne podmienky realizácie individuálnej slobody, lebo kým prvá obchádza subjektivitu, druhá si nevšíma obsahové aspekty reflexívnej slobody, späté s objektívnou realitou sociálnych vzt'ahov, normatívnych praktík. V modernite sa vykryštalizovali tri modely chápania slobody, akcentujúce rozličné podmienky slobodného konania indivídua. „Kým prvá - negatívna - idea je založená na tom, že sloboda jednotlivca si vyžaduje len právne chránenú sféru, v ktorej subjekt môže konat' podl'a vlastných, d'alej nekontrolovaných preferencií, druhá - reflexívna - myšlienka vidí závislost' slobody od realizácie intelektuálneho výkonu, chápaného však ako normálny prejav akéhokol'vek kompetentného subjektu. Až v tretej - sociálnej - idei slobody sa navyše dostávajú k slovu spoločenské podmienky, pretože realizácia slobody je spätá s predpokladom existencie ústretového subjektu, ktorý potvrdzuje moje vlastné ciele“ (Honneth 2018, 112 - 113).

Podl'a Honnetha až Hegel, najmä vo svojej Filozofii práva a vo svojom koncepte Anerkennug, prináša premostenie medzi individuálnou reflexívnou slobodu, založenou na volbe a intelektuálnom výkone, a medzi autonómnou realitou. Od reflexívnej a negatívnej slobody sa dostávame k takzvanej sociálnej slobode.

\section{Uznanie, sloboda a inštitúcie}

Hegel koncipuje pojem uznania (Anerkennung) ako rozhodujúci pre pojem slobody. Tento aspekt zaručuje, že ak sa jedinec, ktorý vo svojej reflexívnej slobode ostáva izolovaný od sociálnych inštitúcii, bude usilovat' o uskutočnenie svojich ciel’ov a zámerov, ich realizácia ostáva neistá, čo sa dá zmiernit' až vtedy, ked' subjekt interaguje $\mathrm{s}$ iným subjektom, $\mathrm{v}$ ktorom vidí partnerský náprotivok pre realizáciu svojich zámerov. Uznanie sa chápe ako recipročná skúsenost's tým faktom, že aj môj partner má túžby a želania, ktoré potvrdzujú moje vlastné. Indivíduá sa musia naučit' zrozumitel'ne artikulovat' svoje priania a aj ich navzájom chápat', skôr než začnú uznávat' svoju vzájomnú závislost'. Na to slúžia inštitúcie uznania, ktoré umožňujú, aby subjekt v správaní iného identifikoval zámery a túžby, ktorých saturácia bude podmienku naplnenia jeho vlastných želaní. Hegel o tomto akte hovorí ako o bytí seba samého 
v inom. Hoci Hegel pôvodne chcel vysvetlit' jednotu spoločnosti z emocionálnych väzieb medzi l’ud'mi, po tom, čo sa zoznámil s národohospodárskym učením, sa obrátil k pojmu ekonomického trhu ako inštitúcii uznávania, ktorá zakladá morálnu jednotu spoločnosti. Inštitúcie nie sú len vonkajším predpokladom intersubjektívnej slobody, ale skôr jej základom a miestom, kde sa sloboda realizuje. Podl’a Hegla indivídua prežívajú a realizujú svoju slobodu len vtedy, ked' participujú na sociálnych inštitúciách, ktoré stelesňujú prax vzájomného uznávania. To má dosah aj na chápanie spravodlivosti, lebo to, čo bude platit' za spravodlivé, už nestačí pomeriavat' podl'a toho, do akej miery jedinci disponujú negatívnou alebo reflexívnou slobodou, ale podl'a toho, do akej miery sa jednotlivým členom spoločnosti zaist'ujú rovnaké šance na participácii inštitúcii uznávania. Takto sa dopracujeme $\mathrm{k}$ tomu, že tieto inštitúcie potrebujú právne zaistenie, podporu občianskej spoločnosti a štátny dozor. ${ }^{16}$

\section{Vzt’ah slobody a spravodlivosti: ich kolízia v liberalizme}

Liberálne demokracie v sebe skrývajú pnutie medzi individuálnou a kolektívnou autonómiou, lebo sféra individuálnej autonómie je chránená právnym systémom, ktorý zaist'uje politické, občianske slobody a právnu sféru nedotknutel’nú zo strany iných subjektov a štátu. Lenže sféra súkromnej, privátnej slobody ako právnej slobody vyžaduje, aby subjekt pri uskutočnení svojich zámerov vstúpil do kontaktu a komunikácie s inými, ktorých uznáva ako právne osoby, ktoré sú síce jednak adresátmi práva, ale na druhej strane tieto práva sú výrazom spoločnej vôle. Ak akceptujeme fakt, že istý koncept slobody podmieňuje isté chápanie spravodlivosti a že liberálny poriadok má v centre negatívnu slobodu a z nej vyrastajúci právny systém, tak spravodlivost' tu predstavuje predovšetkým záruky bezpečnosti jedinca, jeho právom chránené nároky a slobody, nedotknutel'nost' privátnej sféry. ${ }^{17}$ Spoločnost' a jej jednota sa spájajú s predstavou vzájomnej reciprocity jej členov, s kalkulom užitočnosti a produktivity. Už procedurálna spravodlivost' a konštituovanie inštitúcií garantujúcich spravodlivost'sa formuje za podmienok racionálnych kooperujúcich občanov, ktorí dospievajú ku konsenzu, a vlastne všetky zmluvné koncepcie spoločnosti predpokladajú, že politický poriadok je sformovaný na morálnych princípoch férovej kooperácie racionálnych osôb v intencii Kantovho chápania autonómie osoby a jej l'udskej dôstojnosti.

\footnotetext{
${ }^{16}$ Pozri výklad J. Kudrnu K Hegelovým základi̊m filosofie práva, ktorý sleduje historický kontext Heglových názorov v súvislosti s inštitúciami a kl'účovými pojmami. Pozri Hegel (1992, 5 - 20).

${ }^{17}$ Do akej miery nedotknutel'nost' súkromnej sféry platí dnes, v podmienkach zvyšujúcej sa kontroly občanov prostriedkami nových informačných komunikačných technológií, ponechávam bokom. A situácia s reštrikciami a zásahmi do l'udských práv a slobôd spolu so všadeprítomnou kontrolou v núdzovom režime, spustenom v súvislosti s pandémiou nového koronavírusu Covid-19, prináša mnoho otáznikov aj pre teórie reflexívnej, negatívnej aj sociálnej slobody.
} 
Je zrejmé, že idea negatívnej slobody, na nej založená spravodlivost' a predstava o spoločnosti ako sume racionálnych kooperujúcich indivíduí, z nej automaticky vylučujú vel'ké skupiny populácie, ktoré nespĺn̆ajú kritériá racionálneho autonómneho subjektu. K tomu pristupujú aj d’alšie dva problémy, ktoré liberálna koncepcia spoločenského poriadku a spravodlivosti oscilujúcej okolo negatívnej slobody nedokáže vyriešit' - globálna spravodlivost' a problémy práv spätých s druhovou špecifickost'ou (species membership), napríklad práva zvierat. ${ }^{18}$ Ani Rawlsov sociálny liberalizmus a procedurálna distributívna spravodlivost' tieto problémy neriešia, lebo napríklad jeho zoznam dobier nezahŕňa špecifické potreby osôb s nejakou formou postihnutia. ${ }^{19}$

\section{Záver}

Spoločnost' sa nedá redukovat' na kontraktualistickú predstavu, v ktorej sa takto sformovaný poriadok reguluje pravidlami kooperujúcich racionálnych jedincov, hoci táto utopická predstava sa do omrzenia opakuje napriek tomu, že realita jej nastavuje zrkadlo, v ktorom sa odrážajú všetky jej nedomyslenosti a slabé stránky. Hoci sa môže zdat', že otázka slobody, jej politickej hodnoty a vzt'ahu k reflexívnej slobode $\mathrm{v}$ jej dvoch podobách (autonómia a autentickost') je len akademickou témou, navyše historickou, nič nie je vzdialenejšie realite. Práve súčasná civilizačná situácia, navyše skomplikovaná pandémiou nového koronavírusu Covid-19, akoby nanovo otvorila Pandorinu skrinku liberalizmu, respektíve libertariánstva s jeho nárokmi na posledné slovo $\mathrm{v}$ otázke slobody ako nehatenej vol'by indivídua v prospech negatívnej slobody a na ňu nadväzujúcej idey spravodlivosti, predovšetkým ako garancie bezpečnosti jedinca. Táto spravodlivost', ktorá v sebe implicitne zahrnuje napätie medzi politickými právami a slobodami a sociálnoekonomickými právami, zlyháva pri hl'adaní riešení, ako zabezpečit' slobodu a spravodlivost' pre všetkých, čo sa v krajnej podobe prejavuje ako konflikt medzi právom na život a právom na vlastníctvo. ${ }^{20}$

Rétorika liberalizmu povzbudzuje indivíduá, aby presadzovali vlastnú predstavu o št’astí bez ohl'adu na spoločenské blaho a sociálne dobrá. Oslava individua-

\footnotetext{
${ }^{18}$ Nussbaumová vo svojich prácach (napr. Frontiers of Justice) analyzovala a demonštrovala, že tri zásadné problémy sa vymykajú kontraktualistickej perspektíve spoločnosti: osoby s nejakou podobou fyzického alebo duševného postihnutia, globálna spravodlivost' a práva zvierat (Nussbaum 2007, 14-35).

${ }^{19}$ Pozri zoznam dobier, ako ich uvádza Rawls (2007, 99 - 100). O Rawlsovom sociálnom liberalizme pozri Palovičová $(2017,60$ - 64).

${ }^{20}$ M. Muránsky so zretel’om na kritiku libertariánstva rozvíja problematiku dvoch nezlučitel’ných konceptov slobody v súvislosti s problematikou sociálnych ekonomických práv. Pozri Muránsky $(2020,569-583)$.
} 
lizmu vychádzajúceho z predstavy, že predpokladom individuálneho vzostupu a sebarealizácie je odstrihnutie od kolektívu, potom znamená, že takéto indivíduá sú doslovne odsúdené na slobodu $\mathrm{v}$ jej negatívnej forme, pričom sú podriadené prepojeným politickým, ekonomickým a kultúrnym silám. $Z$ tohto aspektu je užitočné, aby sa problematika slobody ako politickej hodnoty podrobila revízii jednak vzhl'adom na lokálne problémy jednotlivých liberálno-demokratických spoločností, jednak so zretel'om na problém globálnej spravodlivosti. Predpokladá to však aj prekonat' odtrhnutost' normatívnych konceptov morálnej aj politickej filozofie od analýzy dnešnej situácie, v ktorej sa spoločnost' nachádza, a normatívne princípy spravodlivosti preskúmat' a analyzovat' so zretel'om na praktiky a inštitúcie, ktoré majú zabezpečit' slobodu v rozličných sférach spoločnosti s prihliadnutím na tie morálne hodnoty, ktoré implicitne stelesňujú. Osobitným problémom ostáva aj vzt'ah medzi individuálnou a kolektívnou autonómiou so zretel'om na ich inštitucionálne garancie a morálne hodnoty, ktoré stelesňujú.

\section{Literatúra}

ARENDTOVÁ, H. (2002): Co je svoboda. In: Mezi minulostí a budoucností. Brno: Centrum pro studium demokracie a kultury.

AYER, A. J., O’ GRADY, J. (eds.) (1994): A Dictionary of Philosophical Quotations. Hobbes, Th. Malden: Blackwell Publishers Oxford, $187-188$.

BARON-COHEN, S. (2014): Věda zla. Brno: Emitos.

BERLIN, I. (1993): Dva pojmy slobody. In: O slobode a spravodlivosti. Bratislava: Archa, 68 - 69.

CAMUS, A. (1993): Mýtus o Sizyfovi, Pád, Caligula. Bratislava: Slovenský spisovatel'.

HAJKO, D. (1993): Št'astný Sizyfos (Pokus o Alberta Camusa) In: CAMUS, A. (1993): Mýtus o Sizyfovi, Pád, Caligula. Bratislava: Slovenský spisovatel', $238-246$.

HAYEK, F. (1991): Právo, zákonodárství a svoboda. Nový výklad liberálních principů spravedlnosti a politické ekonomie. 2) Fata morgána sociální spravedlivosti. Praha: Academia.

HEGEL, G. W. F. (1992): Základy filosofie práva. Praha. Academia.

HONNETH, A. (2018): Právo svobody. Nárys demokratické mravnosti. Praha: Filosofia, nakladatelství Filozofického ústavu AV ČR.

KANT, I. (2006): The Metaphysics of Morals. Cambridge: Cambridge University Press, 30, $6: 238$ ).

KUDRNA, J. (1992): K Hegelovým základům filosofie práva. In: Hegel, G. W. F. (1992): Základy filosofie práva. Praha. Academia, 5-20.

LOCKE, J. (1965): Druhé pojednání o vládě. Praha: Svoboda.

MURÁNSKY, M. (2020): K filozoficko-ekonomickým východiskám sociálnych l'udských práv u Karla Polanyiho a Ernsta Tugendhata. Filozofia, 75 (7), 569 - 583. DOI: https://doi.org/ 10.31577/filozofia.2020.75.7.5

NUSSBAUM, M. (2007): Frontiers of Justice. Disability, Rationality, Species Membership. Cambridge - Massachusetts - London: The Belknap Press of Harvard University Press.

PALOVIČOVÁ, Z. (2017): Ambivalentnost' l'udských práv a neurčitost' ich pojmu z pohl'adu filozofie. Bratislava: Veda.

SEDOVÁ, T. (2020): Filozofia ako životný program. Nad knihou Sarah Bakewellovej. V existencialistické kavárně. Filozofia, 75 (4), 324 - 330. DOI: https://doi.org/10.31577/filozofia.2020.75.4.5

RAWLS, J. (2007): Spravodlivost' ako férovost'. Bratislava: Kalligram. 
SMREKOVÁ, D. (2013): Téma sociálneho a historického v existencializme Jeana-Paula Sartra. In: Novosád, F. - Smreková, D. (eds.): Dejiny sociálneho a politického myslenia. Bratislava: Kalligram. $611-631$.

STRAWSON, F. P. (2001): Sloboda a nevyhnutnost'. In: Analýza a metafyzika. Bratislava: Kalligram, $165-176$.

TOCQEUVILLE, A. (1992): Demokracie v Americe. II. Praha: Lidové noviny.

WILLIAMS, B. (2011): Na počátku byl čin. Realismus a moralismus v politické diskusi. Červený Kostelec: Pavel Mervart.

ZAKARIA, F. (2013): Budoucnost svobody. Neliberálni demokracie v USA i ve světe. Praha: Academia.

Príspevok vznikol v rámci riešenia grantu VEGA 2/0049/20 K idei l’udských práv: filozofická perspektiva - koncepty, problémy, perspektivy.

Tatiana Sedová

Filozofický ústav SAV

Klemensova 19

81364 Bratislava

Slovenská republika

e-mail: tanasedova@gmail.com

ORCID ID: https://orcid.org/0000-0003-1888-9592 